\title{
POLICY PREFERENCES OF POLITICAL PARTY LEADERS AND THE MASS PUBLIC: A SOUTHERN PERSPECTIVE
}

\author{
Mark C. Ellickson \\ (Southwest Missouri State University)
}

\section{Introduction and Literature}

In recent years there has been a steady stream of literature proclaiming the decline of the American party system (Burnham, 1976; Kirkpatrick, 1978; Ladd, 1982; Crotty, 1984, 1985; Konda and Sigelman, 1987). It is argued that the parties have been losing their "relevance," their critical capacity in responding to social needs and problems (Eldersveld, 1982; Miller and Wattenberg, 1983). This allegation entails serious ramifications as political parties have long been viewed as performing many vital functions in the American political system (Leiserson, 1958; Sorauf, 1984).

Concern about party decline seems to have rejuvenated the topic of party reform (Everson, 1980: Sabato, 1988). A major thrust of the reform controversy has centered around the type of party system we should move toward in order to make the parties more effective institutions. One such model which has evoked a fair amount of advocacy, as well as opposition, over the years is what has become known as the "responsible parties" model (Ranney, 1962; Everson, 1980).

A party from the "responsible parties" school of thought is usually depicted as centralized, ideological, and disciplined, while the typical textbook treatment of the American party system describes it as decentralized, pragmatic, and undisciplined. In a much improved conceptualization of the alternative party models, Hitlin and Jackson (1979) suggest that political parties may vary along continuums with respect to three dimensions.

These dimensions are:

1. more national centralized party organizational structures;

2. more issue and ideological coherence within the parties and greater distinctions between the parties, particularly in the electoral appeals they make; and

3. the vesting of some sort of party discipline in a central party body, 
parties as political entities, and suggested a bidimensional conceptualization of partisan identification that consisted of a partisan/non-partisan (i.e., independent) dimension and a Democratic/Republican (partisan) dimension.

Valentine and Van Wingen [1980], who present evidence that independent-leaners are attached to both one of the political parties and to the idea of independence, also conclude that partisan identification ought to be considered bidimensional. Weisberg [1980] has combined the Katz and Valentine-Van Wingen conceptualizations with the hostility hypothesis of Maggiotto and Picreson into a multi-dimensional, cubic model of partisan identification that simultaneously measures subjects' affect toward the Democratic party, the Republican party, and independence.

Keith et al. [1977, 1985], however, have pointed out that independent-leaners, who comprise a majority of the independent category, behave much more like weak partisans than like pure independents in presidential and congressional elections and resemble weak partisans more than pure independents on measures of civic virtue. Consequently, they argue, voting studies should aggregate leaners with partisans rather than with pure independents, if the seven-point scale that differentiates the three groups of independents is not employed. Wekkin [1988] complements Keith et al. by demonstrating that the voting bchavior of independent-leaners even approximates that of weak partisans during primary elections, both in terms of party-ballot selection (in "open" primaries) and candidate preference. He, too, argues, that independent-leaners should be classified with partisans rather than with pure independents when conceptualizing and measuring "crossover voting.'

Shively [1980], on the other hand, questions whether behavioral evidence or even the party thermometer evidence of attachment used by Weisberg, Valentine and Van Wingen, and Maggiotto and Piereson can be considered valid indicators of subjects' identification with a party. Possibly the causal arrow is reversed. Shortterm forces such as the intention or act of voting for a given party's candidates in most races (or in the most salient races) may cue independent identifiers to respond that they "lean" toward or "feel warmly" toward that party, when in fact the implied blurring of psychological space is not present. Thus, what appears to be a measurably distinct category may reduce to a tautology. 


\section{Data and Methodology}

That possibility is addressed in this short study by utilizing an innovative technique to shed new light on the consistency and relative intensity of the psychological orientation of independent-leaners. This technique is derived from the findings of numerous studies (e.g., Jennings \& Niemi [1966]; Elkins [1978]; Clarke et al. [1979]; Blake [1982]; LeDuc et al. [1984]; Hadley [1985]; Maggiotto \& Wekkin [1987]; Niemi et al. [1987]) of Canadian and American partisanship that for a significant share of the electorate in federal systems, partisan orientations are differentiated by level of government. The hypothesis tested here is that if independent-leaners' partisan inclinations are in fact cued reflections of their voting intentions, then these inclinations should alter considerably as the federal context in which partisan identification is assessed changes. In a Southern state such as Arkansas, for example, where voters are notorious ticket-splitters ${ }^{1}$ who often support Republicans in presidential contests, Democrats in courthouse and legislative contests, and may swing either way in given congressional and gubernatorial elections, one might expect independent-leaners to exhibit considerable volatility in their professed orientations as the governmental context of those orientations changes from national to state to local politics.

This hypothesis was tested twice during the course of a broader study of multiple partisanship in Arkansas' Second Congressional District, where fairly intense two-party competition has characterized presidential and some congressional contests during the 1980s, while state and local elections-with the exception of the 1980 gubernatorial contest - have continued to be dominated by Democrats. In the first empirical test, we asked 402 systematically-selected participants in a 4 November 1986 exit-poll to respond to three national, state, and local-oriented variations of the partisan identification question, ${ }^{2}$ separated in each instance by the standard contingency questions to probe the strength of partisan attachment and the direction in which independents leaned, if any. Then, in order to have additional measures for contrast, we also employed standard, open-ended questions that asked what the respondents liked and disliked about each of the political parties. ${ }^{3}$ Voters were interviewed immediately after leaving the polls at 17 precincts located throughout the second congressional district, a mixed urban/rural area that includes most of the Greater Little Rock SMSA. This was the third such poll to sample these precincts, which had 
been randomly selected in 1982 from a universe of 448 precincts in the eight counties that comprise the district. The sample results were representative (i.e., within sampling error) of the universe with respect to electoral outcomes in all races for office. Also, despite the tendency of voters to overrepresent the middle and higher strata of society, the sample was quite representative demographically, as well. ${ }^{4}$

In the second test, which took the form of an exit-poll conducted during the 1988 presidential primary held on "Super Tuesday," we asked 573 systematically-selected participants in the same precincts (plus two) to respond to the same three federallydifferentiated partisan identification questions, augmented this time by a thermometer test to provide additional information about the partisan affect of the various categories of respondents. Again, the sample results were within sampling error with respect to electoral outcomes in all races for office.

\section{Findings}

The data in Table 1 do not suggest that independent-leaners are especially fickle or tenuous in their commitment to their professed orientation. In fact, Democratic-leaners and Republican-leaners are less likely to change their political orientation (as one governmental context is substituted for another) than two, usually three of the four partisan categories are. In every case except the Democratic-leaning independents in panel $\mathrm{A}$, independent-leaners are extremely consistent in their stated attachments, whether measured as a percentage of the category or in comparison with other categories. Only pure independents and strong Democrats (whose consistency is buoyed by the Southern tradition of "yellow-dog loyalty") exceed the two sets of independent-leaners in consistency of identification. Three-way crosstabulation shows that 62 percent of those who claimed to be independent-leaners at any of the three levels of the federal system were stalwart independent-leaners at all three levels. This, in a sample in which 26 percent of all respondents were found to be multiple partisans (i.e., professed different party identifications as state and/or local political contexts were substituted for the national), is a fairly impressive rate of consistency.

The consistency of identification found in the 1986 sample gave way somewhat when the second district was resampled during the Spring, 1988 primary. Under ballot-restrictions that one might expect would 
possibly enhance the consistency of identification, if Shively is correct about the influence of leaners' votes upon their professions of identity, respondents to the 1988 exit-poll actually tended to be less, not more, consistent in partisan orientation. Three-way cross-tabulation revealed that only about 30 percent of those who professed to be an independentleaner at some level were stalwart independent-leaners at all three levels. But then 33 percent of the respondents to the sample were multiple identifiers, and, as Table 2 shows, consistency of identification dropped so much in every category of the seven-point scale that Democratic-leaners, at least, continued to rank ahead of two of the four partisan groups.

Given Arkansans' reputation for ticket-splitting, not to mention the psychological pull that the state's modified one-party Democratic culture must exert on independents, one should expect to find many multiple identifiers in the independent-leaner categories if Shively's hunch that the orientation follows the vote is correct. But one does not find many in the 1986 sample, and the rate of inconsistency or multiple identity among independent-leaners in the 1988 sample is lower or proximate to that among weak and strong Republicans in panels $\mathrm{A}$ and $\mathrm{B}$ of Table 2. The central hypothesis of this study thus earns little support, in these two samples, at least.

Nor does the frequently much higher still rate of stalwartness among pure independents in Table 1 and 2 suggest that this category and those of the independent-leaners are separated by nothing more than their respective voting intentions, or the relative amount of introspection involved in their respective questionnaire responses. Despite their consistency of orientation relative to several of the partisan categories, it remains that independent-leaners are still less likely than pure independents to identify themselves consistently as independents in all political contexts. The differences between independent-leaners and pure independents thus appear to be at least partly differences of psychological space, and not merely a matter of responses to short-term cues.

\section{Open-Ended \& Thermometer Evidence}

Whether such differences should be attributed to psychological space or to short-term influences may be further tested by examining the open-ended evidence collected in the 1986 sample, and the party-thermometer evidence collected in the 1988 sample. Analysis of 
the former tends to reinforce the above evidence and, in so doing, the Keith et al. [1985] position regarding the placement of leaners with partisans in both theory and measurement. The percentage of 1986 respondents who answered open-ended questions regarding what they liked and disliked about the respective parties was 47 percent, which compares favorably to that in national samples and provides a large enough $(\mathrm{N}=189)$ and demographically similar enough sample ${ }^{6}$ to permit nonparametric testing of intratabular differences between independent-leaners and other types of identifiers.

As Tables 3 and 4 demonstrate, Democratic-leaning independents and Republican-leaning independents generally share the same levels of positive affect as partisan identifiers toward their preferred parties. Leaners are much more likely than pure independents, oppositeleaners, and opposite-partisans to make positive comments about their preferred party, and negative comments about the opposing party. Indeed, in 14 of the 24 possible cases in which the attitudes of the appropriate set of independent-leaners are contrasted to those of the other two categories of independents, the differences discovered are great enough to be significant at the .05 level. Clearly, independent-leaners of both types resemble partisans much more than they resemble their fellow independents; so much so, in fact, that the old problem of intransitivity rears its head in several places. Republican-leaning independents at every level of the polity were considerably more likely than Republican identifiers to condemn the Democratic party, and were also slightly more likely than state and local Republican identifiers to make favorable comments about the Republican party. Democratic-leaners, in contrast, exceeded Democratic partisans only once at making favorable comments about their favored party or negative comments about the disfavored party, but in any case resembled those partisans more closely in affect than they resembled their fellow independents.

It also is apparent in these tables that pure independents stand apart from independent-leaners in their propensity to make negative comments about both political parties. Whereas Republican-leaners at every level and Democratic-leaners at the national level tend to evaluate their respective preferred parties more favorably than negatively (state and local Democratic-leaners evince balanced views of their preferred party), pure independents at each level evaluate both parties negatively, usually by margins that match or exceed those of opposing partisan identifiers. The mean percentage of negative comments made about political parties by pure independents is 88 percent with respect to the 
Democratic party and 64 percent with respect to the Republican party, compared to means of 39 and 37 percent making comments favorable to the Democrats and Republicans, respectively. Computations not shown in the tables reveal that 41 percent of the respondents who designated themselves to be pure independents at one or more levels of the polity made only negative comments about one or both political parties (three out of four of these made strictly negative comments about both parties), while another 29 percent made at best balanced comments (i.e., evenly distributed favorable/unfavorable responses) about the parties.

Interpretation of such clear predilections on the part of each category should be qualified, of course, to the extent that many of these 189 respondents made mixed comments stating likes and dislikes about one or both political parties. It is possible to take such multidimensional responses into account by assigning values to each type of comment made and creating a crude partisan-affect index score for each category of respondents. We have assigned respondents one point for a positive remark about the party they identify with or lean toward, one point for a remark unfavorable to the opposing party, and have deducted respondents one point for a remark unfavorable to their own party and for a remark favorable to the opposing party. Thus, the maximum partisan score a respondent might receive is +2 , a score of 0 would indicate offsetting remarks, and -2 represents the maximum in disaffection toward one's party. Employing this scale, Democratic and Republican identifiers who volunteered responses to the open-ended questions achieved index scores of 0.89 and 1.31, respectively, compared to index scores of 0.46 and 1.37 for Democratic-leaners and Republican-leaners, respectively. Once again, intransitivity is found to occur at the juncture of Republican-leaners and Republican identifiers, whereas Democratic-leaners prove much less enthusiastic partisans than are Democratic identifiers.

Although pure independents who disclaim attachment to either party cannot be predicted to register favorable or unfavorable comments toward either party, we nevertheless may compare their scores to those of both sets of partisans and independent-leaners by arbitrarily treating them as a category expected to favor the Democrats, and then repeating the procedure in the expectation they would favor the Republicans. Following this procedure, pure independents registered an index score of -0.27 toward the Democratic party, and +0.27 toward the Republican party. Thus, once again, independents prove much less favorable than independent-leaners in affect toward the parties, but markedly less 
hostile toward the Republicans than toward the Democrats, who, as the dominant party in the state, are perhaps the obvious referent for antipartisan sentiment.

Finally, analysis of the specific content of these open-ended responses uncovers little support for Shively's thesis that independentleaners respond as they do because of the quality of candidates or other short-term considerations. Of those 32 independent-leaners who troubled to explain what they liked about the party they tilted toward, 41 percent cited party policies, 25 percent cited party beliefs/ideologies, 13 percent cited the party's candidates, 9 percent cited the party's group affiliations, and another 13 percent cited general reasons. When asked what they specifically disliked about the party they tilted away from, 48 percent of the 30 independent-leaners who responded cited the party's policies, 19 percent cited its ideology, 11 percent cited its candidates, and a similar percentage cited its group affiliations and general reasons, respectively. Although these particular data are questionable at best because of diminutive sample size and because of the selectivity that is a concomitant of open-ended items (i.e., those virtuous enough to answer are probably more inclined to view politics in ideological or policy-conscious terms), they are nevertheless consistent with the preceding indicators that suggest that independent-leaners tilt toward parties for dispositional reasons, not as a byproduct of their evaluation of short-term considerations.

\section{Thermometer Evidence}

This is suggested still further by the thermometer evidence gathered during the 1988 Super Tuesday sample. Table 5 shows that consistent or "global" independent-leaners' thermometric evaluations of the Democratic and Republican parties, respectively, tend more toward those of the consistent partisans than toward those of consistent pure independents, and that this closeness is, once again, accentuated by intransitivity in the partisan scale at the juncture of independent-leaners and weak partisans. Consistent leaners' evaluations of political independents, on the other hand, tend to be closer to those of the consistent pure independents than to those of the consistent partisans-so much so, in fact, that Democratic-leaners even rate independents much more favorably than the pure independent respondents do.

Moreover, each of these tendencies holds up, albeit in somewhat weaker manner, upon inspection of the thermometric eval- 
uations given by all self-identified independent-leaners, whether they consistently identify themselves as such or not (see Table 6). Consequently, the thermometer data confirm but also amend the open-ended data in that the independent-leaners in this sample appear to qualify as partisans, not independents, in terms of affect toward the favored and disfavored parties, respectively, while also categorizeable as independents, not partisans, in terms of their feelings toward their fellow independents.

\section{Conclusions}

What shall we make of the latter finding, or of this study's principal finding that independent-leaners are more consistent than several partisan categories, but less consistent than pure independents, in political orientation toward the three levels of government? Both findings suggest the centrality of partisan feeling as well as that of independence in the cognitive structure of independent-leaners. On the one hand, unlike pure independents, who registered neutral thermometric evaluations and usually volunteered negative open-ended evaluations of one or both political parties, the independent-leaners in these samples clearly evince positive psychological ties toward one party and negative feelings toward the other party according to both measures. On the other hand, unlike partisan indentifiers, these same independent-leaners also registered relatively favorable thermometric evaluations of independent identifiers. Given these tendencies, and the comparative persistence with which independent-leaners stuck by their selfcategorization besides, one would have to conclude that if Shively's thesis is correct, then it would have to be as true of those in the other categories of the partisan identification scale as it is of independentleaners.

The sensible conclusion would appear to be that it is as inappropriate to dismiss independent-leaners as basically incognizant "pure" independents as it is for Keith et al. [1985] and Wekkin [1988] to recommend the expedient of lumping independent-leaners together with partisans or weak partisans whenever one uses the three-point or five-point partisan scales. The thrust of this study is that independentleaners are so distinct from both partisans and fellow independents that the seven-point partisan scale should never be collapsed when analyzing partisanship. Nor should one conceptualize independence, as the revisionists are wont to do, as a political orientation so different 
from partisanship that it should not even be included in partisan scales. Clearly, the two sets of independent-leaners qualify effectively for inclusion in such scales, even if pure independents arguably do not. At the same time, however, the standard view of partisanship as a scale arranged along a single-dimensional continuum does not conduce a sufficiently subtle understanding of the various blends of partisan and independent shades that were found to characterize the independentleaners in this study. Ultimately, the data presented here may reconcile best with Weisberg's [1980] multidimensional conceptualization, which models partisanship as a cube constructed of separate, but connected planes representing the respondent's simultaneous orientations toward the Democrats, the Republicans, and Independents, respectively. But that is a question for more elaborate study.

\section{Notes}

${ }^{1}$ In 1968, for example, Arkansas voters shocked political analysts by electing J.W. Fulbright, a Democrat, to the U.S. Senate, Winthrop Rockefeller, a Republican, as governor, and George Wallace's American Independent Party slate to the Electoral College. More recently, during the 1980 elections Arkansans elected Republicans in the presidential, gubernatorial and two of four congressional contests, while Democrats won all but seven legislative seats, two county judgeships, one county sheriff's office, and a dozen or so quorum court (county board) seats in a state of 75 counties.

${ }^{2}$ Wording of the partisan identification-items was as follows:

*Thinking now only of national politics, do you usually consider yourself to be a Democrat, a Republican, an Independent, or what? ... (contingencies).

*Thinking now only of state politics here in Arkansas, do you usually consider yourself to be a Democrat, a Republican, an Independent, or what? ... (contingencies).

*Thinking now only of local politics here in your community, do you usually consider yourself to be a Democrat, a Republican, an Independent, or what? . . (contingencies).

${ }^{3}$ Question-items read: "What do you like and/or dislike about the Democratic party?... What do you like and/or dislike about the Republican party?" Several lines of space clearly marked "Like" and "Dislike" followed both items.

${ }^{4}$ For example, 86 percent of the sample respondents were white, whereas census data show 83 percent of the population of the Second District (and of Arkansas) to be white; 53 percent of the respondents were males, compared to census figures of 


\section{Maggiotto and Wekkin}

48 percent for both the district and the state; the median years of education completed by respondents was 13.2 compared to census figures of 12.4 for the district and 12.2 for the state; the median family income of respondents was $\$ 22,030$, compared to census figures of $\$ 22,700$ for the district and $\$ 19,114$ for the state; and the median age of the respondents was 39 years, compared to census figures of 29 for the district and 31 for the state. The 1988 sample was even closer to updated census data for gender and median years of education, within sampling error for median age and racial distribution, and slightly outside sampling error for family income.

${ }^{5}$ For the question-wording and introduction used in this test, see the note at the bottom of Table 5 .

${ }^{6}$ For example, 89 percent of those who responded to the open-ended questions were white, compared to 86 percent of the total sample; 23 percent were occupied in professional-technical fields, compared to 19 percent of the total sample; 16 percent were liberals, compared to 17 percent of the total sample; 5 percent lacked a high school diploma, compared to 9 percent of the sample, etc. 


\section{Table 1}

\section{Consistency of Partisan Identification as Federal Context Changes, 1986}

Panel A: Percentage Whose Party ID Remains Constant When Context Shifts from National to State Politics

Ind. Ind.

Str. Weak Lean Pure Lean Weak Str.

Dem. Dem. Dem. Ind. Rep. Rep. Rep.

\section{Percentage} of Consistent

$\begin{array}{llllllll}\text { Identifiers } & 97.1 \% & 89.6 \% & 67.6 \% & 92.7 \% & 82.4 \% & 55.8 \% & 77.1 \% \\ \mathrm{~N}= & 104 & 77 & 37 & 55 & 34 & 43 & 35\end{array}$

Panel B: Percentage Whose Party ID Remains Constant When Context Shifts from National to Local Politics

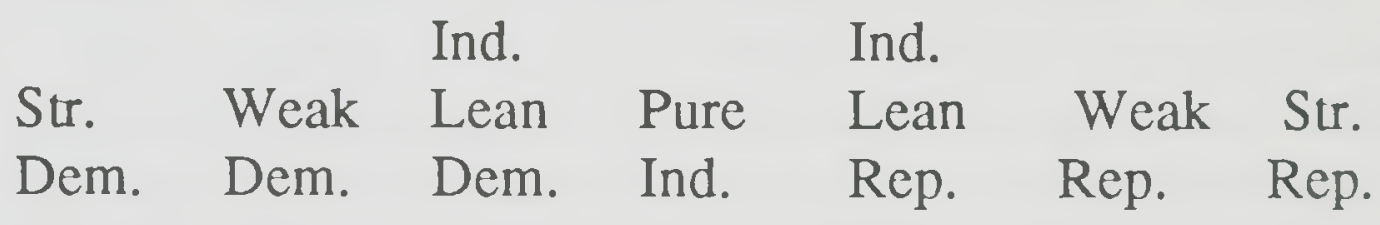

Percentage of Consistent

\begin{tabular}{llllllll} 
Identifiers & $92.3 \%$ & $80.0 \%$ & $83.3 \%$ & $90.7 \%$ & $94.1 \%$ & $40.5 \%$ & $51.4 \%$ \\
$\mathrm{~N}=$ & 104 & 75 & 36 & 54 & 34 & 42 & 35 \\
\hline
\end{tabular}

Panel C: Percentage Whose Party ID Remains Constant When Context Shifts from State to Local Politics

Ind. Ind.

Str. Weak Lean Pure Lean Weak Str.

Dem. Dem. Dem. Ind. Rep. Rep. Rep.

Percentage

of Consistent

Identifiers

$89.5 \% \quad 77.3 \%$

$83.7 \%$

$98.3 \%$

$92.3 \%$

$63.6 \% \quad 59.1 \%$

$\mathrm{N}=$ 


\section{Maggiotto and Wekkin}

\section{Table 2}

\section{Consistency of Partisan Identification as Federal Context Changes, 1988}

Panel A: Percentage Whose Party ID Remains Constant When Context Shifts from National to State Politics

Ind. Ind.

Str. Weak Lean Pure Lean Weak Str.

Dem. Dem. Dem. Ind. Rep. Rep. Rep.

Percentage of Consistent Identifiers $\begin{array}{lllllll}93.5 \% & 64.9 \% & 55.3 \% & 63.6 \% & 32.6 \% & 45.5 \% & 47.2 \%\end{array}$

$\begin{array}{llllllll}\mathrm{N}= & 139 & 111 & 38 & 33 & 46 & 77 & 106\end{array}$

Panel B: Percentage Whose Party ID Remains Constant When Context Shifts from National to Local Politics

Percentage

Ind. Ind.

Str. Weak Lean Pure Lean Weak Str.

Dem. Dem. Dem. Ind. Rep. Rep. Rep.

of Consistent

Indentifiers $\quad 82.6 \% \quad 57.7 \% \quad 48.6 \% \quad 88.6 \% \quad 26.7 \% \quad 43.4 \% \quad 43.1 \%$

$\begin{array}{llllllll}\mathrm{N}= & 138 & 111 & 37 & 35 & 45 & 76 & 102\end{array}$

Panel C: Percentage Whose Party ID Remains Constant When Context Shifts from State to Local Politics

Percentage

Ind. Ind.

of Consistent

Identifiers

$\begin{array}{lllllll}78.5 \% & 60.5 \% & 47.8 \% & 81.6 \% & 39.4 \% & 74.1 \% & 65.1 \%\end{array}$

$\mathrm{N}=$

172

129

46

49

33

54

63 


\section{Table 3}

Percentage of Respondents Making Favorable and Unfavorable Comments About the Democratic Party

Panel A: Partisan Identification With Respect to National Politics

\begin{tabular}{|c|c|c|c|c|c|}
\hline & Dem. & $\begin{array}{l}\text { Ind. } \\
\text { Lean } \\
\text { Dem. }\end{array}$ & $\begin{array}{l}\text { Pure } \\
\text { Ind. }\end{array}$ & $\begin{array}{l}\text { Ind. } \\
\text { Lean } \\
\text { Rep. }\end{array}$ & Rep. \\
\hline Favorable & $68 \%$ & $78 \%$ & $32 \%$ & $33 \%$ & $36 \%$ \\
\hline Unfavorable & $41 \%$ & $61 \%$ & $77 \%$ & $100 \%$ & $86 \%$ \\
\hline$N=$ & 91 & 18 & 22 & 21 & 36 \\
\hline \multicolumn{6}{|c|}{ Panel B: Partisan Identification With Respect to State Politics } \\
\hline & & $\begin{array}{l}\text { Ind. } \\
\text { Lean }\end{array}$ & Pure & $\begin{array}{l}\text { Ind. } \\
\text { Lean }\end{array}$ & \\
\hline & Dem. & Dem. & Ind. & Rep. & Rep. \\
\hline Favorable & $74 \%$ & $50 \%$ & $42 \%$ & $40 \%$ & $22 \%$ \\
\hline Unfavorable & $41 \%$ & $56 \%$ & $92 \%$ & $100 \%$ & $85 \%$ \\
\hline $\mathrm{N}=$ & 97 & 16 & 24 & 20 & 27 \\
\hline
\end{tabular}

Panel C: Partisan Identification With Respect to Local Politics

$\begin{array}{lccccc} & & \begin{array}{l}\text { Ind. } \\ \text { Lean } \\ \text { Dem. }\end{array} & \begin{array}{l}\text { Pure } \\ \text { Ind. }\end{array} & \begin{array}{l}\text { Ind. } \\ \text { Lean } \\ \text { Rep. }\end{array} & \text { Rep. } \\ \text { Favorable } & 72 \% & 69 \% & 50 \% & 21 \% & 15 \% \\ \text { Unfavorable } & 41 \% & 69 \% & 92 \% & 100 \% & 77 \% \\ \mathrm{~N}= & 95 & 13 & 38 & 19 & 13\end{array}$


Table 4

Percentage of Respondents Making Favorable and Unfavorable Comments about the Republican Party

Panel A: Partisan Identification With Respect to National Politics

$\begin{array}{lllll} & \text { Ind. } & & \text { Ind. } & \\ & \text { Lean } & \text { Pure } & \text { Lean } & \\ \text { Dem. } & \text { Dem. } & \text { Ind. } & \text { Rep. }\end{array}$

Favorable

$12 \%$

$17 \%$

$36 \% \quad 86 \%$

$92 \%$

Unfavorable

$81 \%$

$50 \%$

$64 \%$

$43 \%$

$42 \%$

$\mathrm{N}=$

91

18

22

21

36

Panel B: Partisan Identification With Respect to State Politics

\begin{tabular}{lcclll} 
& & $\begin{array}{l}\text { Ind. } \\
\text { Lean } \\
\text { Dem. }\end{array}$ & $\begin{array}{l}\text { Pure } \\
\text { Ind. }\end{array}$ & $\begin{array}{l}\text { Ind. } \\
\text { Lean } \\
\text { Rep. }\end{array}$ & Rep. \\
Favorable & $22 \%$ & $19 \%$ & $29 \%$ & $95 \%$ & $85 \%$ \\
Unfavorable & $76 \%$ & $56 \%$ & $71 \%$ & $55 \%$ & $37 \%$ \\
$\mathrm{~N}=$ & 97 & 16 & 24 & 20 & 27 \\
\hline
\end{tabular}

Panel C: Partisan Identification With Respect to Local Politics

$\begin{array}{lccccc} & & \begin{array}{l}\text { Ind. } \\ \text { Lean } \\ \text { Dem. }\end{array} & \begin{array}{l}\text { Pure } \\ \text { Ind. }\end{array} & \begin{array}{l}\text { Ind. } \\ \text { Lean } \\ \text { Rep. }\end{array} & \text { Rep. } \\ \text { Favorable } & 21 \% & 23 \% & 50 \% & 95 \% & 92 \% \\ \text { Unfavorable } & 81 \% & 62 \% & 61 \% & 42 \% & 23 \% \\ \mathrm{~N}= & 95 & 13 & 38 & 19 & 13\end{array}$




\section{Table 5}

\section{Consistent (Non-Multiple) Identifiers' Affective Responses to the Parties} As Measured by Feelings Thermometer, 1988*

$\begin{array}{llllll} & & \text { Ind. } & & \text { Ind. } & \\ \text { Str. } & \text { Weak } & \text { Lean } & \text { Pure } & \text { Lean } & \text { Weak Str. } \\ \text { Dem. } & \text { Dem. } & \text { Dem. } & \text { Ind. } & \text { Rep. } & \text { Rep. Rep. }\end{array}$

Mean Thermometric

Evaluation of

Democratic party

$83^{\circ} \quad 63^{\circ} \quad 59^{\circ} \quad 45^{\circ} \quad 34^{\circ} \quad 41^{\circ} \quad 22^{\circ}$

Mean Thermometric

Evaluation of

Independents

$27^{\circ} \quad 31^{\circ} \quad 70^{\circ} \quad 50^{\circ} \quad 49^{\circ} \quad 42^{\circ} \quad 34^{\circ}$

Mean Thermometric

Evaluation of

Republican Party

$25^{\circ}$

$45^{\circ}$

$33^{\circ}$

$53^{\circ}$

$65^{\circ}$

$75^{\circ}$

$91^{\circ}$

$\mathrm{N}=$

$108 \quad 52 \quad 13$

178

$28 \quad 38$

"Questions were prefaced and asked in the following manner: "Below is a 'political thermometer' to test your feelings about certain people and groups. Its temperature range runs from 100 degrees, which means you have very warm feelings toward a person or group, to 0 degrees, which means you feel very cool toward a person or group. A temperature of about 50 degrees would mean you have neutral feelings toward a person or group ... (thermometer pictured)

Where would you place your feelings toward the Republican party on this thermometer? degrees

Where would place your feelings toward the Democratic party on this thermometer? degrees

Where would you place your feelings toward Independents on this thermometer? degrees." 
Table 6

Affective Responses to the Parties of All Identifiers (Consistent and Inconsistent Combined) As Measured by Feelings Thermometer, 1988*

Mean Thermometric

Evaluation of

Democratic Party

$\begin{array}{lllllll}79^{\circ} & 60^{\circ} & 56^{\circ} & 43^{\circ} & 34^{\circ} & 38^{\circ} & 25^{\circ}\end{array}$

Mean Thermometric

Evaluation of

Independents

$28^{\circ} \quad 35^{\circ} \quad 51^{\circ} \quad 45^{\circ} \quad 44^{\circ} \quad 33^{\circ} \quad 34^{\circ}$

Mean Thermometric

Evaluation of

Republican Party

Str. Weak Lean Pure Lean Weak Str.

Dem. Dem. Dem. Ind. Rep. Rep. Rep.

$\mathrm{N}=$

$28^{\circ}$

$49^{\circ} \quad 43^{\circ}$

$61^{\circ}$

$72^{\circ}$

$78^{\circ}$

$88^{\circ}$

$\begin{array}{lll}154 & 95 & 30\end{array}$

$48 \quad 33$

53

63

"Questions worded as in Table 5.

\section{References}

Blake, Donald E. 1982. "The Consistency of Inconsistency." Canadian Journal of Political Science 15 (December): 691-710.

Campbell, Angus, Philip E. Converse, Warren E. Miller, and Donald E. Stokes. 1960. The American Voter. New York: Wiley.

Clarke, Haroid D., Jane Jenson, Lawrence LeDuc, and John H. Pammett. 1979. Political Choice in Canada. Toronto: McGraw-Hill-Ryerson.

Elkins, David J. 1978. "Party Identification: A Conceptual Analysis." Canadian Journal of Political Science 11 (June): 419-435.

Hadley, Charles D. 1985. "Dual Partisan Identification in the South." Journal of Politics 47 (February): 254-268.

Jennings, M. Kent and Richard G. Niemi. 1966. "Party Identification at Multiple Levels of Government." American Journal of Sociology 72: 86101.

Katz, Richard J. 1979. "The Dimensionality of Partisan Identification: CrossNational Perspectives." Comparative Politics 11 (January) 147-163. 


\section{Independent-Leaners in the Partisan Identification Scale}

Keith, Bruce E., David B. Magleby, Candice J. Nelson, Elizabeth Or, Mark Westlye, and Raymond E. Wolfinger. 1977. "The Myth of the Independent Voter." Paper delivered at the annual meeting of the American Political Science Association, Washington, D.C., September 1977.

1985. "The Partisan Affinities of Independent 'Leaners'." British Journal of Political Science 16: 155-184.

LeDuc, Lawrence, Jane Jenson, John Pammett, and Harold D. Clarke. 1984. "Partisan Instability in Canada: Evidence from a New Panel Study." American Political Science Review 78 (June): 470-484.

Maggiotto, Michael A. and James E. Piereson. 1977. "Partisan Identification and Electoral Choice: The Hostility Hypothesis." American Journal of Political Science 21 (November): 745-767.

and Gary D. Wekkin. 1987. "Global Concepts and Segmented Partisans: Rejoining Theory and Data." Paper Delivered at the annual meeting of the Southwestern Political Science Association, Dallas, Tex., 20 March 1987.

Niemi, Richard G., Stephen Wright, and Lynda W. Powell. 1987. "Multiple Party Identifiers and the Measurement of Party Identification." Journal of Politics 49 (November): 1093-1103.

Petrocik, John R. 1974. "An Analysis of Intransitivities in the Index of Party Identification." Political Methodology 1(Summer): 31-47.

Shively, W. Phillips. 1980. "The Nature of Party Identification: A Review of Recent Developments." John C. Pierce and John L. Sullivan, eds. The Electorate Reconsidered. Beverly Hills: Sage Publications.

Valentine, David C. and John R. Van Wingen. 1980. "Partisanship, Independence, and Partisan Identification." American Politics Quarterly 8 (April): 165-186.

Weisberg, Herbert F. 1980. "A Multidimensional Conceptualization of Party Identification." Political Behavior 2 (1): 33-60. 363-376. 1983. "A New Scale of Partisanship." Political Behavior 5 (4):

Wekkin, Gary D. 1988. "The Conceptualization and Measurement of Crossover Voting." Western Political Quarterly 41 (February): 105-114. 